$\begin{array}{ll}\text { Abstracta Iranica } & \begin{array}{l}\text { Abstracta Iranica } \\ \text { Revue bibliographique pour le domaine irano-aryen }\end{array} \\ & \text { Volume } \mathbf{2 8} \mid \mathbf{2 0 0 7} \\ & \text { Comptes rendus des publications de } \mathbf{2 0 0 5}\end{array}$

\title{
« Le buste d'homme encerclé achéménide : Buste divin ou buste royal ». Orient-Express, 2005/2, pp. 35-38, une figure.
}

\section{Astrid Nunn}

\section{CpenEdition}

\section{Journals}

Édition électronique

URL : http://journals.openedition.org/abstractairanica/15792

DOI : 10.4000/abstractairanica.15792

ISSN : 1961-960X

Éditeur :

CNRS (UMR 7528 Mondes iraniens et indiens), Éditions de l'IFRI

\section{Édition imprimée}

Date de publication : 15 mai 2007

ISSN : 0240-8910

Référence électronique

Astrid Nunn, « «Le buste d'homme encerclé achéménide : Buste divin ou buste royal ». Orient-Express, 2005/2, pp. 35-38, une figure. », Abstracta Iranica [En ligne], Volume 28 | 2007, document 88, mis en ligne le 18 septembre 2007, consulté le 25 septembre 2020. URL : http://journals.openedition.org/ abstractairanica/15792 ; DOI : https://doi.org/10.4000/abstractairanica.15792

Ce document a été généré automatiquement le 25 septembre 2020

Tous droits réservés 


\section{« Le buste d'homme encerclé achéménide : Buste divin ou buste royal ». Orient-Express, 2005/2, pp. 35-38, une figure.}

\section{Astrid Nunn}

L'A. nous informe dans cet article exceptionnellement long pour la revue Orient-Express de ses recherches sur le buste encerclé. En effet selon lui l'interprétation la plus courante selon laquelle ce buste représente Ahuramazda sous son aspect lunaire est fausse. Le cercle est souvent déformé, le croissant de lune et le buste encerclé prennent une position tout à fait distincte dans l'iconographie et enfin l'emploi du croissant lunaire et celui du buste inscrit ne sont pas contemporains: trois arguments pour étayer l'hypothèse selon laquelle le buste d'homme encerclé représente le Grand Roi achéménide. Pourquoi pas? L'article est néanmoins trop court pour convaincre pleinement. Cette théorie demande plus ample réflexion iconologique sur le contexte général de ce motif. Est-il pensable que le roi apparaisse seul et en buste entre deux atlantes sous le disque ailé ? Quelle serait la fonction du roi en buste encerclé quand il apparaît avec une autre figure qui pourrait, elle aussi, représenter le roi (BM 89422) ?

\section{INDEX}

Thèmes : 3.2.2. Pré-Achéménides et Achéménides 
AUTEURS

ASTRID NUNN

Université de Munich 